\title{
A Survey on Product of Smart Service System
}

\author{
Moh. Roufiq Azmy \\ School of Electrical Engineering and Informatics \\ Institut Teknologi Bandung \\ Bandung, Indonesia \\ roufiq@students.itb.ac.id
}

\begin{abstract}
Smart service is a new value that results from a collaboration between service providers and service users. Company as a service provider transformed not only provide a physical product, but also provide services. We conducted this research to in tegrate knowledge between smart products and smart service systems. The conceptualization of smart products is done by conducting a literature study of previous research. It is use d to obtain the characteristics of smart products on smart service systems. This research also presents various topics and research focus in the context of products on smart service systems by including several smart service system implementations and illustration of smart product
\end{abstract}

Keywords-smart service system, product-service system, service design

\section{PENDAHULUAN}

Beberapa dekade terakhir ini, kata "smart" atau cerdas menjadi jargon yang disematkan pada berbagai hal, seperti sistem cerdas, kota cerdas, atau produk cerdas. Kata cerdas tersebut menggambarkan kemajuan teknologi, sosial, dan ekonomi yang didukung oleh teknologi yang mengandalkan sensor, Big Data, open data, dan teknik baru konektivitas dan pertukaran informasi (misalnya IoT, RFID, dan NFC), serta kemampuan untuk berpikir dan mengambil keputusan [1]. Hal tersebut dapat terlihat dari kemunculan layanan yang memiliki produk fisik yang terhubung secara digital dengan produk lain untuk menjalankan berbagai proses bisnis yang kompleks pada berbagai bidang seperti manufaktur, pendidikan, transportasi, atau kesehatan.

Produk cerdas membentuk suatu kolaborasi untuk menciptakan layanan cerdas yang didasarkan pada monitoring, optimasi, pengendalian jarak jauh, sehingga sistem layanan tersebut bertransformasi menjadi sistem layanan cerdas. Kolaborasi tersebut juga menciptakan nilai baru dari segi perspektif pengguna maupun penyedia layanan. Misalnya pada layanan smart mobility, kendaraan yang semula hanya sebagai mesin/alat transportasi kini dibekali dengan perangkat pemrosesan data yang dapat mengenali kondisi di sekitarnya (kon disi jalan, posisi kendaraan lain), terhubung dan berkomunikasi dengan perangkat cerdas atau infrastruktur transportasi (sistem informasi transportasi, sistem gerbang tol), dan mampu beradaptasi berdasarkan analisis dari data yang dikumpulkan untuk menghasilkan keputusan dengan cepat mendekati real-time (sistem pengereman yang diaktifkan ketika kondisi berbahaya atau darurat) [2]. Pada bidang yang lain misalnya sistem layanan cerdas Laundy View pada jasa laundry dengan memanfaatkan mesin cuci yang terhubung dengan internet, memungkinkan calon pelanggan dapat mencari jasa atau mesin cuci yang tersedia dalam suatu 
area. Mesin tersebut juga dibekali perangkat yang dapat mendeteksi jika terjadi gangguan dan melaporkan kerusakan atau memberikan saran bagi penyedia layanan laundry tersebut [3].

Meskipun terdapat hubungan yang kuat secara teknis dan kontekstual antara produk cerdas dengan sistem layanan cerdas, kedua hal tersebut memiliki area penelitian yang berbeda. Hal tersebut yang mendasari penulis membahas aspek produk cerdas pada sistem layanan cerdas. Pengetahuan memahami bagaimana menciptakan suatu produk bagi sistem layanan cerdas dan tren teknologi yang diadopsi oleh produk cerdas sangat penting untuk dilakukan. Sejauh identifikasi yang dilakukan oleh penulis saat ini, belum ada studi sebelumnya yang dilakukan untuk kategorisasi karakteristik produk cerdas dan aspek teknis yang berkaitan dengan penerapan produk cerdas pada sistem layanan cerdas. Oleh karena itu, kontribusi dari penelitian ini adalah memberikan visi yang lebih dalam makna dari produk cerdas pada layanan cerdas, karakteristik dari produk cerdas, bagaimana mendesain suatu produk cerdas, tren teknologi yang diadopsi oleh suatu produk cerdas dan aspek teknis penerapan produk cerdas pada sistem layanan cerdas, serta pencapaian penelitian terdahulu terkait produk cerdas pada sistem layanan cerdas.

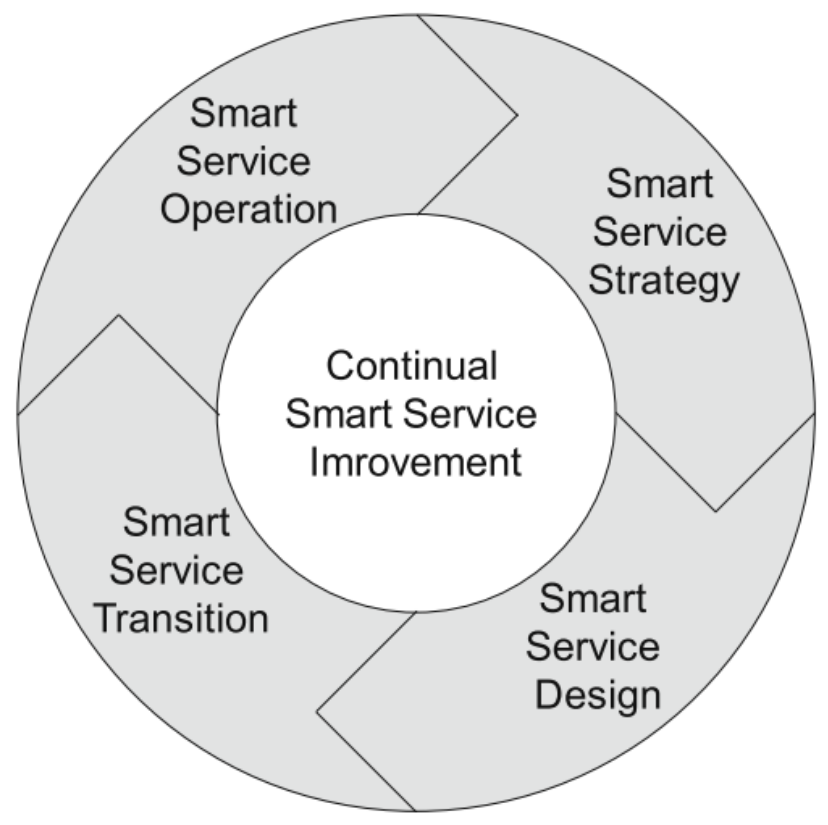

Gambar 1 : Model siklus hidup layanan cerdas

Artikel yang disajikan berisi ulasan naratif tentang studi yang telah dilakukan sebelumnya terkait pengembangan produk cerdas pada sistem layanan cerdas. Penulis melakukan ringkasan pada studi terpilih dan melakukan kategorisasi berdasarkan pendekatan kualitatif. Tujuannya adalah menyajikan beberapa penelitian terkini dan memberikan visi yang menyeluruh bagaimana mendesain suatu produk cerdas yang digunakan pada sistem layanan cerdas.

Struktur penyajian dari penelitian ini adalah sebagai berikut. Bagian II menjelaskan konseptualisasi dari produk cerdas dan layanan cerdas. Bagian III menjelaskan karakteristik dari produk layanan cerdas yang dilanjutkan pada Bagian IV yang menjelaskan bagaimana mendesain sistem layanan cerdas yang menghasilkan suatu produk dengan memperhatikan aspek teknis dan tren teknologi yang digunakan. Bagian $\mathrm{V}$ memaparkan studi terdahulu 
mengenai penerapan produk cerdas pada berbagai lingkungan sistem layanan cerdas. Bagian VI merupakan kesimpulan dari seluruh isi penelitian ini.

\section{KONSEPTUALISASI DARI PRODUK CERDAS DAN LAYANAN CERDAS}

Terdapat perdebatan bagaimana mendefinisikan suatu layanan cerdas, berbagai peneliti mencoba mengemukakan pendapat dan menekankan sudut pandang dan karakteristik yang berbeda dari topik tersebut. Anke,dkk dan Garilova,dkk. menyatakan layanan cerdas merupakan suatu kolaborasi antara pengguna dan penyedia layanan yang dihubungkan dalam sebuah sistem [4] dan mesin yang dibekali dengan kecerdasan [5]. Melalui kolaborasi tersebut, penyedia layanan dapat mengetahui kebutuhan pengguna saat ini sebagai dasar strategi untuk menyediakan layanan cerdas yang berkelanjutan. Wiegard dan Breitner menyatakan layanan cerdas merupakan kombinasi dari layer fisik dan digital menghasilkan layanan yang memberikan nilai tambah yang didasarkan pada produk cerdas (seperti smart wearable device) [6]. Dreyer,dkk menyatakan layanan cerdas merupakan solusi layanan yang bersifat individual, dinamis, dan berkualitas yang menekankan kebutuhan pelanggan diwujudkan dengan kecerdasan pada suatu bidang dengan menganalisis teknologi berbasis data lingkungan dan sosial di sekitarnya (beberapa secara real-time) [7]. Analisis tersebut menghasilkan nilai kolaborasi antara pengguna dan penyedia layanan pada seluruh fase pengembangan strategis untuk peningkatan layanan cerdas, dimana siklus hidup dari layanan cerdas dapat dilihat pada Gambar.1 terdiri dari lima fase yaitu 1.) Fase strategi layanan cerdas yang mendefinisikan tujuan proses berdasarkan kebutuhan pengguna, strategi layanan dan kemampuan layanan. 2.) Fase perancangan layanan cerdas, menggunakan strategi yang telah ditentukan untuk merancang layanan. 3.) Fase transisi layanan cerdas, menggambarkan cara mengubah atau menerapkan layanan baru. 4.) Fase operasi layanan cerdas meliputi manajemen kegagalan, pemeliharaan, dan pelaksanaan tugas dan proses; dan 5.) Fase peningkatan berkelanjutan layanan cerdas, mempelajari keberhasilan dan kegagalan masa lalu kemudian menyesuaikan layanan secara berkelanjutan, menggunakan data dan informasi terkait, dan melibatkan pengguna. Penelitian tentang sistem layanan cerdas dari sudut pandang lain dikemukakan oleh Laubis,dkk yang menyatakannya sebagai sistem yang didesa in untuk manajemen mandiri (selfmanagement) dan konfigurasi ulang mandiri (self-reconfiguration) untuk memastikan penyediaan layanan yang memenuhi kebutuhan pengguna [8]. 


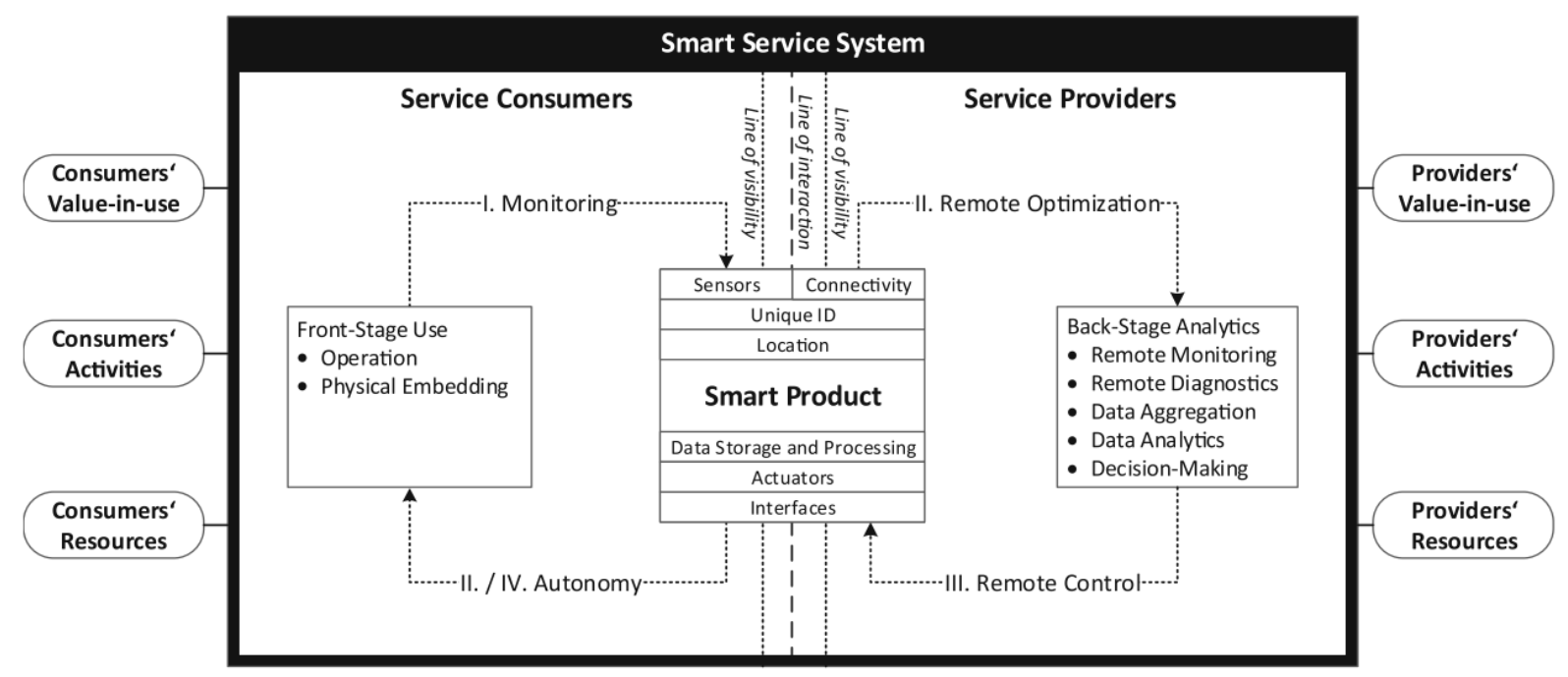

Gambar 2 : Konseptualisasi sistem layanan cerdas menggunakan produk cerdas sebagai pembatas. Gambar diambil dari [9]

Beverungen,dkk Menyatakan bahwa menyatakan bahwa layanan cerdas adalah penerapan kompetensi khusus, melalui tindakan, proses, dan kinerja yang dimungkinkan oleh produk cerdas, sedangkan sistem layanan cerdas adalah sistem layanan di mana smart product sebagai objek batas yang mengintegrasikan sumber daya dan kegiatan aktor yang terlibat untuk saling menguntungkan. [9] Lebih lanjut Beverungen menjelaskan pada penelitian lain bahwa layanan cerdas dibentuk dengan memperkenalkan perangkat cerdas ke dalam sistem layanan digital. [10]Kompetensi jaringan digital perangkat cerdas dari para aktor yang berada pada sistem layanan digital dan / atau menengahi interaksinya. Perangkat cerdas menampilkan fitur fisik dan digital secara bersamaan, sehingga mereka dapat mengamati, mengidentifikasi, dan menganalisis peristiwa fisik dan digital, membuat keputusan, dan melakukan tindakan fisik dan / atau digital. Oleh karena itu, layanan pintar mengintegrasikan kompetensi fisik dan digital dalam sistem layanan sosioteknik yang kompleks.

Berdasarkan Pandangan yang dinyatakan oleh berbagai peneliti dapat ditarik kesimpulan jenis produk sistem layanan cerdas dapat dibagi menjadi tiga kategori: berorientasi hasil, berorientasi penggunaan, dan berorientasi produk [3]. Pada sistem layanan cerdas berorientasi hasil, perusahaan atau penyedia layanan lebih mengutamakan menjual hasil atau keahlian daripada produk nyata. Penyedia menjadi pihak yang bertanggung jawab atas pemeliharaan kondisi dan performa produk cerdas. Di sisi lain, sistem layanan cerdas yang berorientasi pada penggunaan, fungsi produk lebih menonjol. Penyedia layanan menjual aksesibilitas dan manfaat dari suatu produk cerdas. Misalnya pada layanan penyewaan mesin http://www. boels.com, penyedia masih memegang kepemilikan atas suatu produk dengan tujuan memelihara usia produk, sedangkan pengguna sela in membayar aksesibilitas juga bertanggung jawab terhadap selama masa pemakaian dan melaporkan jika terjadi kerusakan. Pada kategori ketiga, yaitu sistem layanan cerdas yang berorientasi produk, penyedia layanan menjual produk cerdas dan terjadi kepemilikan dari penyedia ke pengguna. Beberapa layanan juga ditambahkan untuk menjamin kualitas dan fungsionalitas dari produk tersebut. 


\section{KARAKTERISTIK PRODUK LAYANAN CERDAS}

Salah satu tujuan umum dari penelitian ini adalah menyediakan pengetahuan dalam menyusun produk layanan cerdas. Hal tersebut dapat tercapai dengan pemahaman suatu produk cerdas dengan penekanan interaksi atau pengalaman pengguna, sehingga dapat menciptakan hubungan jangka panjang antara penyedia dengan pengguna layanan. Berdasarkan studi yang telah dilakukan, terdapat enam karakteristik dari produk cerdas yang dijelaskan pada Tabel 1.

Pengguna merupakan instrumen kunci dalam hal pengenalan produk cerdas. Bentuk dari produk cerdas yang berupa digital menjadikan akun pengguna sebagai cara untuk mengenali penggunanya. Berkaitan dengan akun pengguna, produk cerdas dapat menyediakan virtual servicescapes untuk berkomunikasi dengan penggunanya. Servicescapes merupakan environment dimana interaksi antara penyedia layanan dan pengguna terjadi. Bebera pa produk cerdas menyediakan web portal yang dapat diakses melalui komputer, sedangkan pada produk lainnya pengguna dapat mengakses virtual servicescapes tersebut langsung melalui produk cerdasnya. Amazon Kindle merupakan salah satu perangkat yang dapat menyediakan kedua opsi tersebut. Pengguna dapat mengakses Kindle Store untuk membeli layanan melalui ereader, atau mengaksesnya melalui internet menggunakan komputer yang berbeda. Karena pengguna diidentifikasi menggunakan akun personal pada masing-masing perangkat, maka konten yang telah dibeli menggunakan akun tersebut secara otomatis dilakukan sinkronisasi pada tiap virtual servicescapes.

Berbagi dan berkomunitas yang dimaksud adalah bagaimana produk cerdas memfasilitasi interaksi antar pengguna. Komunikasi dapat dilakukan seperti di sosial media. Penyedia layanan dapat melakukannya dengan menyediakan sebuah platform agar pengguna dapat saling berinteraksi terkait pengalamannya menggunakan produk cerdas untuk saling berbagi data atau mendapatkan feedback/saran dari penggunanya. Implementasi penggunaan media yang tepat memiliki dampak yang signifikan dalam menjaga momentum terhadap penggunaan produk cerdas. Beberapa hal yang perlu diperhatikan, karena pengguna dapat berinteraksi satu sama lain, maka review yang negatif terhadap pengalaman menggunakan produk cerdas berdampak negatif terhadap pemasaran produk cerdas. Dibalik itu semua, implementasi platform interaksi pengguna mendorong penyedia layanan berinteraksi langsung dengan pengguna, menyediakan informasi yang diperlukan oleh pengguna, membangun dan memantau opini dari pengguna.

Pengalaman pengguna berhubungan dengan sejauh mana pengalaman menggunakan produk cerdas. Pendekatan yang dilakukan oleh Nike+ misalnya mendorong pengguna yang terhubung dalam suatu kelompok untuk dapat saling berkompetisi dalam mencapai target individu mereka. Informasi pengalaman menggunakan produk cerdas suatu pengguna dicatat dan dibandingkan dengan pencapaian pengguna lain dalam bentuk gamifikasi yang menyenangkan. Penyedia layanan perlu memperhatikan level yang diinginkan pengguna, karena dapat menyebabkan perbedaan tujuan dan definisi dalam penggunaan produk cerdas tersebut. Demikian juga, penyedia layanan perlu menyadari seluruh aspek yang mempengaruhi pengalaman individu pengguna. Misalnya produk cerdas yang dibeli oleh pengguna secara personal, pengalaman yang diharapkan tidak hanya berfokus dalam memenuhi kebutuhan pengguna, namun perlu dipikirkan secara estetika produk tersebut. 
TABLE I.

RINGKAS AN KARAKTERISTIK DARI PRODUK CERDAS

\begin{tabular}{|c|c|c|}
\hline Karakteristik & Deskripsi & Contoh \\
\hline $\begin{array}{l}\text { 1. Pemberdayaan } \\
\text { Pengguna }\end{array}$ & $\begin{array}{l}\text { Memungkinkan pengguna untuk membuat } \\
\text { keputusan ataumengambil suatuaksi berdasarkan } \\
\text { indikator yang telah ditentukan. Dilakukan } \\
\text { dengan: } \\
\text { - Menyediakan feedback berupa informasi yang } \\
\text { relevan bagi pengguna } \\
\text { - Mengubah data menjadi informasi } \\
\text { - Menampilkan informasi terkait kondisi } \\
\text { produk/layanan } \\
\text { - Menyediakan opsi atau pilhan bagi pengguna }\end{array}$ & $\begin{array}{l}\text { - Menampilkan grafik yang memungkinkan pengguna untuk } \\
\text { mengetahui perkembangan suatukondisi } \\
\text { - Menampilkan perkiraan waktu pada suatu lokasi yang } \\
\text { ditunjukkan pada peta digital } \\
\text { - Menampilkan deskripsi produk/layanan dan/atau review } \\
\text { pengguna }\end{array}$ \\
\hline $\begin{array}{l}\text { 2. Personalisasi } \\
\text { layanan }\end{array}$ & $\begin{array}{l}\text { Menjadikan pengguna merasa bagian penting } \\
\text { dengan mengenalinya sebagai individu unik }\end{array}$ & $\begin{array}{l}\text { - Identifikasi dari pengguna } \\
\text { - Menggunakan layanan digital untuk berkomunikasi langsung } \\
\text { dengan pengguna } \\
\text { - Menggunakan natural language ketika menampilkan informasi } \\
\text { atau berkomunikasi dengan pengguna }\end{array}$ \\
\hline $\begin{array}{ll}\text { 3. } & \begin{array}{l}\text { Berbagi dan } \\
\text { berkomunitas }\end{array} \\
\end{array}$ & $\begin{array}{l}\text { Memfasilitasi interaksi antar pengguna dalam } \\
\text { bentuk komunitas }\end{array}$ & $\begin{array}{l}\text { - Menyediakan platform untuk interaksi saling berbagi data atau } \\
\text { informasi terkait layanan atau produk yang digunakan }\end{array}$ \\
\hline $\begin{array}{l}\text { 4. Pengalaman } \\
\text { Pengguna }\end{array}$ & $\begin{array}{l}\text { Memungkinkan untuk berbagi pengalaman } \\
\text { melalui produk cerdas }\end{array}$ & $\begin{array}{l}\text { - Mendorong pengguna untuk senantiasa menggunakan produk } \\
\text { cerdas, misalnya dalam bentuk gamifikasi dan berbagi } \\
\text { pengalaman }\end{array}$ \\
\hline $\begin{array}{l}\text { 5. } \begin{array}{l}\text { Kepemilikan } \\
\text { produk }\end{array}\end{array}$ & $\begin{array}{l}\text { Menentukan siapa yang bertanggung jawab atas } \\
\text { kondisi produk dari waktu ke waktu }\end{array}$ & $\begin{array}{l}\text { - Produk yang disewakan } \\
\text { - Produk dimiliki oleh pengguna } \\
\text { - Produk dimiliki oleh pengguna namun berbagi dengan yang lain }\end{array}$ \\
\hline $\begin{array}{l}\text { 6. Perkembangan } \\
\text { yang kontinu }\end{array}$ & $\begin{array}{l}\text { Memfasilitasi perkembangan atau evolusi dari } \\
\text { sistem layanan cerdas }\end{array}$ & $\begin{array}{l}\text { - Memperkenalkan fitur/fungsionalitas baru dari suatu produk } \\
\text { cerdas secara berkala } \\
\text { - Menyediakan sistem terbuka bagi pengembang lain untuk } \\
\text { menciptakan fitur atau fungsionalitas baru dari produk cerdas }\end{array}$ \\
\hline
\end{tabular}

Karakteristik dari kepemilikan suatu produk cerdas berpengaruh terhadap model bisnis dari produk tersebut. Terdapat dua tipe kepemilikan suatu produk cerdas. 1.) Produk cerdas yang bersifat fisik/nyata dijual kepada pengguna secara langsung sehingga berganti kepemilikan.

Pada kasus ini, pengguna yang bertanggung jawab secara langsung atas pemeliharaan produk tersebut. Pemeliharaan ini meliputi instalasi pembaruan perangkat lunak yang dikembangkan oleh penyedia layanan, untuk menjamin suatu produk cerdas mendapatkan fungsionalitas yang diharapkan. Kepemilikan produk cerdas secara pribadi oleh pengguna juga memungkinkan akses yang tidak terbatas penggunaan produk cerdas, kecuali dibatasi oleh ketentuan bisnis yang disediakan oleh penyedia layanan. Amazon Kindle merupakan salah satu produk cerdas yang memenuhi tipe ini. 2.) Kepemilikan suatu produk cerdas masih berada pada penyedia layanan, dimana penyedia layanan bertanggung jawab terhadap pemeliharaan fungsionalitas suatu produk. Berbeda dengan tipe sebelumnya dimana kepemilikan dialihkan kepada pengguna, pada tipe ini pengguna berinteraksi dengan penyedia layanan untuk mendapatkan perkembangan yang kontinu berhubungan dengan bagaimana produk cerdas senantiasa beradaptasi dan memberikan nilai dari waktu ke waktu. Tujuan dari penerapan pertumbuhan berkelanjutan untuk menjaga share market, dan mempertahankan keterlibatan interaksi pengguna dengan produk cerdas. Produk yang mengadopsi perkembangan teknologi dengan cepat berpeluang untuk menyediakan nilai yang relevan bagi pengguna. Beberapa strategi dapat diterapkan untuk menjaga perkembangan produk cerdas. Sebagai contoh, secara periodik penyedia layanan merilis pembaruan yang berisi fungsionalitas baru pada produk cerdas. Strategi yang lain yang dapat diterapkan dapat dilakukan dengan menyediakan sistem terbuka bagi pengembang lain untuk berkontribusi untuk menambah fungsionalitas dari produk cerdas. Strategi ini banyak diterapkan oleh perusahaan pembuat ponsel cerdas atau perangkat mobile. Pada akhirnya, penyedia layanan juga dapat membuka layanannya kepada pengguna untuk berkolaborasi menciptakan nilai baru bagi sebuah sistem layanan cerdas.

(C) Asosiasi Prakarsa Indonesia Cerdas (APIC) - 2019 
TABLE II. TOPIK DAN FOKUS PENELITIAN TERDAHULU DALAM KONTEKS DESAIN LAYANAN CERDAS

\begin{tabular}{|c|c|}
\hline Topik & Fokus \\
\hline Big Data & $\begin{array}{ll}\text { - } & \text { Analisis Data } \\
\text { - } & \text { Pentingnya data bagi layanan cerdas } \\
\end{array}$ \\
\hline Keterlibatan pengguna & $\begin{array}{ll}\text { - } & \text { Peran Pengguna pada layanan cerdas } \\
\text { - } & \text { Kebutuhan Pengguna }\end{array}$ \\
\hline Knowledge management & $\begin{array}{ll}\text { - } & \text { Teknologi untuk pemrosesan infomasi } \\
\text { - } & \text { Sarana menampilkan dan menerapkan informasi } \\
\end{array}$ \\
\hline Machine Learning & $\begin{array}{l}\text { - Pendekatan untuk fungsionalitas yang spesifik } \\
\text { - Pendekatan penggunaan machine learning untuk layanan cerdas }\end{array}$ \\
\hline Keamanan dan privasi & $\begin{array}{l}\text { - Konsep role dan manajemen pengguna } \\
\text { - Masalah kemanan dan privasi }\end{array}$ \\
\hline Kualitas layanan & $\begin{array}{l}\text { - Mengukur kualitas dari suatu layanan cerdas } \\
\text { - Aspek dari kualitas layanan cedas }\end{array}$ \\
\hline Standardisasi & $\begin{array}{ll}\text { - } & \text { Standardisasi dari data dan informasi } \\
\text { - } & \text { Standardisasi dari aspek teknologi } \\
\end{array}$ \\
\hline Teknologi & $\begin{array}{ll}\text { - } & \text { Prespektif teknologi pada layanan cerdas } \\
\text { - } & \text { Penggunaan teknologi yang tepat bagi layanan cerdas } \\
\end{array}$ \\
\hline Tren & - $\quad$ Tren masa depan layanan cerdas \\
\hline Perilaku pengguna & - Mengukur dan menganalisis perilaku pengguna \\
\hline Antarmuka pengguna & $\begin{array}{l}\text { - Contoh antarmuka pengguna pada layanan cerdas } \\
\text { - Kontribusi teoritis bagaimana antarmuka pengguna mendukung layanan cerdas }\end{array}$ \\
\hline
\end{tabular}

\section{DESAIN LAYANAN CERDAS}

Beberapa penelitian mendesain layanan cerdas telah dilakukan sebelumnya mengadopsi model gambar. 1. Ringkasan topik dan fokus penelitian tersebut dapat dilihat pada Table II. Studi literatur menunjukkan pada fase desain layanan cerdas, aspek standardisasi, keamanan, dan privasi paling banyak mendapat perhatian dan menjadi topik penelitian sebelumnya. Pada aspek standardisasi kesimpulan yang didapatkan adalah bahwa suatu standar diperlukan untuk menggabungkan dan memperluas layanan cerdas yang sesuai dengan kebutuhan pengguna [11]. Aspek privasi menjadi concern dalam berbagai penelitian Misalnya pada [1] peneliti memiliki concern terhadap privasi data wisatawan yang berbasis lokasi pada layanan smart tourism. Meskipun memiliki manfaat bagi dirinya, namun juga me mbuat penggunanya rentan terhadap ancaman. Penelitian yang dilakukan oleh [12] juga mendefinisikan keamanan informasi pada layanan cerdas di bidang kesehatan (Smart Health) menjadi enam aspek yang digunakan untuk menyusun arsitektur smart health, yaitu: keamanan fisik, keamanan jaringan, host security, keamanan aplikasi, keamanan data, dan manajemen keamanan secara keseluruhan.

Terdapat enam hal yang dapat dilakukan terkait dengan data, khususnya Big Data, yaitu 1.) mengumpulkan/mengambil data, 2.) menyimpan dan memberikan indeks, 3.) membagikan/ berkolaborasi, 4.) memproses, 5.) mempublikasikan, dan 6.) mengarsipkan [13]. Salah satu pemanfaatan Big Data dalam layanan cerdas digunakan pada Smart Tourism, dimana data dikumpulkan dari berbagai sumber dan perangkat, baik secara aktif seperti data yang dipunggah ke media sosial; atau secara pasif seperti sensor pada perangkat mobile atau wearable device [1]. Salah satu karakteristik Big Data yaitu data yang terdiri dari berbagai sumber logic dan physical, dikumpulkan dan diabstraksi menjadi resource object. Data tersebut 
dilakukan analisis untuk menghasilkan resource map yang memetakan ketergantungan antar resource. Resource map tersebut dapat digunakan untuk deteksi penyebab kegagalan jaringan pada sebuah rumah, atau dapat digunakan untuk menghasilkan komposisi layanan baru yang bersifat dinamis [14].

Beberapa penelitian menggambarkan bagaimana keterlibatan pengguna dalam proses desain layanan cerdas. Pentingnya keterlibatan pengguna diperlihatkan oleh fakta bahwa value dari layanan cerdas harus dibuat bersama (co-created) [15]. Kebutuhan untuk mendeskripsikan keinginan pengguna menjadi bentuk layanan yang dapat diinterpretasikan oleh mesin menjadi tantangan tersendiri, khususnya oleh perangkat IoT. Salah satu alternatif yang dapat dilakukan adalah mengkombinasikan Semantic Web dengan Ubiquitous Web yang berfokus pada teknologi untuk memungkinkan akses Web bagi siapa saja dan menggunakan perangkat apa pun. Metode tersebut diimplementasikan dengan menggunakan REpresentational State Transfer for Things (Thing-REST), dimana penelitian yang dilakukan oleh [16] menguji keefektifan metode tersebut pada smart plant watering-service application

Belum banyak penelitian yang dilakukan mengenai manajemen pengetahuan (know ledge management) dan machine learning pada layanan cerdas. Hal ini cukup menarik karena pada layanan cerdas, interpretasi terhadap data adalah hal penting. Pengetahuan memungkinkan peningkatan penyediaan layanan cerdas dan memastikan bahwa masalah dan tan tangan di masa lalu tidak bertahan di masa depan. Karena itu, basis pengetahuan harus diisi, dipelihara, dan digunakan. [17]. Layanan cerdas seringkali beradaptasi sesuai dengan kebutuhan pengguna. Pengetahuan didapatkan dari kejadian di masa lampau, sedangkan pengetahuan dari seseorang dan sumber data yang lain memungkinkan untuk terus meningkatkannya. Machine learning memungkinkan untuk mengubah data menjadi informasi yang juga berkontribusi pada peningkatan berkelanjutan. Karena layanan cerdas adalah perkembangan yang relatif baru, pendekatan praktik terbaik belum ditetapkan. Penelitian yang memberikan solusi tentang bagaimana manajemen pengetahuan dan machine learning untuk layanan cerdas dapat dirancang menarik baik untuk teori dan praktik. Terkait dengan desain, perlu juga diperhatikan bagaimana menanamkannya ke dalam konteks yang berbeda

Peningkatan kualitas layanan merupakan salah satu hal penting yang perlu dilakukan agar sistem layanan cerdas dapat terus berkembang. Terdapat beberapa metode yang dapat dilakukan untuk mengukur kualitas dari layanan cerdas. Salah satu contoh menggunakan model matematis yang menerapkan algoritma dengan prasyarat yang ditentukan sebelumnya dan menentukan apakah hal tersebut sudah dipenuhi oleh layanan cerdas yang ada saat ini [18] Pendekatan lain adalah penyediaan daftar indeks yang digunakan untuk membantu mengukur kualitas layanan berdasarkan pertimbangan mengenai penyedia layanan, pelanggan, dan platform [19]

Perkembangan teknologi dan inovasi dari layanan cerdas mampu mengubah model bisnis suatu perusahaan penyedia layanan. IBM yang dahulu dikenal sebagai perusahaan manufaktur dan menjual berbagai perangkat komputer dan TI kini bertransformasi menjadi perusahaan yang menyediakan layanan yang relevan dengan kebutuhan pelanggan seiring dengan perkembangan jaman. [20] Hal ini pula yang mendorong para penyedia layanan untuk berupaya menciptakan ide layanan cerdas baru. Terdapat berbagai penelitian yang dilakukan sebelumnya bagaimana mendesain suatu layanan cerdas baru. Salah satu diantaranya adalah menggunakan 
framework yang mengintegrasikan inovasi dengan perkembangan teknologi dan faktor pengguna [21] yang dapat dilihat pada Fig.3. Framework tersebut dikembangkan dengan memanfaatkan analisis morfologi untuk mengintegrasikan ketertarikan pasar sebagai representasi kebutuhan pengguna dan perkembangan teknologi sebagai faktor pendorong dalam pembuatan layanan yang baru. Tahapan yang dilakukan adalah membangun dimensi dari layanan dan teknologi. Dimensi layanan dibangun untuk mencerminkan aspek layanan cerdas yang berpusat pada pengguna. Pengguna tidak hanya memperoleh nilai dari suatu produk atau layanan, tetapi juga secara aktif mengonsumsi, mengubah, dan bahkan berpartisipasi dalam proses penciptaan nilai layanan cerdas [22]. Dimensi teknologi dinyatakan dalam entitas teknologi yang terdiri dari perangkat, prosedur, dan keterampilan sumber daya manusia yang dimiliki.

\section{IMPLEMENTASI PRODUK SISTEM LAYANAN CERDAS}

Layanan cerdas tidak akan terwujud tanpa kolaborasi antara penye dia layanan dan pengguna. Penyedia layanan dapat dipandang sebagai sebuah perusahaan/industri yang menyediakan produk dan/atau layanan yang dapat dimanfaatkan oleh pengguna. Suatu perusahaan yang dahulu menghasilkan suatu produk kini juga menghasilkan layanan yang menunjang atau berkaitan dengan produk tersebut. Table III menunjukkan ringkasan implementasi sistem layanan cerdas pada berbagai bidang, dimana klasifikasi yang dilakukan mengadopsi standar ISIC (International Standard Industrial Classification). Standar tersebut menggambarkan kompetensi pada masing-masing bidang penyedia layanan. Kontribusi nilai tambah yang diberikan oleh layanan cerdas dapat diukur dari sisi ekonomisnya, sehingga dapat dibandingkan secara nasional maupun internasional.

Pada kategori bidang pertanian, inovasi layanan cerdas yang dihasilkan berupa smart farming/smart agriculture. Smart Farming merupakan sistem layanan cerdas berbasis pengetahuan dan teknologi multi agent [23]. Pengetahuan dibangun menggunakan Augmented Intelligence (AI). Produk layanan cerdas berupa agent yang dapat bekerja secara otonom dan adaptif. Agen lahan digunakan untuk melakukan penjadwalan kunjungan ke lahan pertanian, dan menjadi kontrol terhadap kondisi lahan. Agent satelit dapat menangkap pola lahan yang mengalami masalah, sedangkan agen drone dapat membuat penjadwalan untuk mendapatkan gambar detail kondisi lahan. Agen pemupukan melakukan penjadwalan untuk melakukan pemupukan dan menentukan dosis takaran pupuk secara otomatis.

Seiring dengan perkembangan teknologi, integrasi antara energi dan informasi menciptakan model bisnis baru pada layanan Smart Grid. Advance Metered Infrastructure (AMI) menjadi salah satu produk layanan cerdas [24] yang menggabungkan jaringan sensor, smart meters, dan perangkat lunak yang memberdayakan pengguna untuk dapat melakukan kontrol terhadap penggunaan energi, seperti listrik, air, dan bahan bakar. Pada kategori pengelolaan dan daur ulang sampah, sistem layanan cerdas yang dihasilkan berupa Smart Waste Management [25]. Produk layanan cerdas berupa tempat sampah cerdas yang memiliki sensor untuk mengukur bobot dari sampah dan tingkat kapasitas dari tempat sampah. Sensor tersebut dapat membaca, mengumpulkan data, dan mengirimkan data tersebut melalui internet Hal tersebut sangat berguna dalam melakukan penjadwalan dan manajemen sampah pada sebuah kota.

Peningkatan produktivitas dan keamanan dalam suatu proyek konstruksi merupakan prioritas utama bagi penyedia layanan konstruksi. Beberapa teknologi diadopsi untuk menyediakan alat 
yang meningkatkan produktivitas dan keamanan dengan mengumpulkan data terkait keadaan sekitar proyek konstruksi dan pengambilan keputusan menggunakan GPS, Real Time Locator System (RTLS). AMC dan AMG digunakan untuk melakukan simulasi secara real time g una meningkatkan keamanan dalam proses pengerjaan konstruksi [26], pencegahan tabrakan pada dua crane di suatu lokasi dan pencegahan kecelakaan kerja pada proses ekskavasi/penggalian bawah tanah.

Pada bidang transportasi dan pergudangan, terdapat berbagai sistem layanan cerdas yang dapat dikembangkan. Sistem rekomendasi transportasi dapat dikembangkan dengan memanfaatkan data pada perangkat mobile dan data sistem transportasi publik yang sudah dibekali dengan sensor [27]. Pengguna yang menggunakan aplikasi tersebut dapat memperoleh moda transportasi cocok dengan mempertimbangkan faktor biaya, kenyamanan, dan waktu perjalanan. Infrastruktur jalan raya sebagai pilar utama penunjang transportasi darat juga perlu mendapatkan perhatian. Penelitian yang dilakukan oleh [28] mencoba kondisi permukaan jalan dengan memanfaatkan data yang dikirimkan oleh perangkat mobile. Perangkat mobile saat ini yang dibekali oleh berbagai sensor seperti akselerometer, GPS, gyroscope. Data dari berbagai sensor tersebut diproses untuk memperkirakan kondisi permukaan jalan raya yang sedang dilalui oleh pengguna. Selain itu perusahaan yang bergerak di bidang distribusi barang memiliki sistem layanan warehouse untuk memastikan setiap proses dan posisi dapat dipantau. Kegiatan tersebut meliputi perencanaan stok, pengiriman stok menuju titik penjemputan, pengambilan barang, dan monitor moda transportasi pengangkut barang. Penelitian yang dilakukan oleh [29] mencoba mengimpelementasikan Smart Warehouse System dengan memanfaatkan aplikasi yang membaca data yang dikirimkan oleh sensor GPS, termasuk penggunaan robot yang dapat mempercepat waktu pencarian barang di dalam gudang [30]

Perkembangan jumlah penduduk dan kendaraan pribadi merupakan salah satu permasalahan bagi suatu kota dalam menyediakan lahan parkir. Penelitian yang dilakukan oleh [31] mencoba mendeskripsikan teknologi yang dapat digunakan dalam layanan Smart Parking. Layanan tersebut meliputi bagaimana pengguna dapat menemukan lahan parkir hingga layanan untuk melakukan parkir secara aman. Teknologi yang digunakan meliputi sensor inframerah, sensor ultrasonik, sensor optik, dan sensor metal. Data dari berbagai sensor tersebut dapat ditransmisikan melalui koneksi Bluetooth, Wifi, hingga jaringan seluler.

Kehadira pelanggan adalah factor penting dalam industri akomodasi dan makanan seperti restoran. Salah satu faktor kunci yang menentukan kepuasan pelanggan adalah kecepatan untuk menyajikan layanan sesuai dengan pesanan. Produk cerdas yang dikembangkan pada layanan Smart Restaurant Management and Ordering System memiliki kemampuan untuk: 1.) menangani reservasi dan pemesanan menu 2.) manajemen rekomendasi menu 3.) memodelkan menu secara 3D 4.) Analisis sentimen dan kepuasan pelanggan [32]. Layanan ini juga dapat berkolaborasi dengan layanan cerdas yang lain misalnya fintech untuk menangani pembayaran pesanan.

Smart Campus mengacu pada kegiatan yang mengintegrasikan berbagai sistem aplikasi layanan, menyiapkan lingkungan pengajaran, pembelajaran, yang cocok untuk manajemen, pengajaran, penelitian ilmiah, dan kesatuan kehidupan kampus, serta berdasarkan Internet of Things (IoT), membentuk sistem terintegrasi dengan kerja sama dan kemampuan penyesuaian diri. Beberapa produk cerdas yang diimplementasikan pada sistem layanan Smart Campus 
antara lain Campus Mobile Phone Card, yaitu mengintegrasikan teknologi RFID dengan SIM Card pada perangkat seluler. Produk cerdas tersebut menjadi "pintu akses" untuk memanfaatkan berbagai layanan yang tersedia di lingkungan kampus, seperti presensi kehadiran, layanan peminjaman buku atau fasilitas kampus. [33]. Menggunakan teknologi RFID yang diterapkan sebelumnya, pengguna dapat melakukan pencarian buku perpusatan secara mandiri dan melakukan peminjaman.

Sistem layanan cerdas pada bidang kesehatan dapat didefinisikan sebagai kegiatan monitoring berkelanjutan terhadap keadaan suatu pasien dan status kesehatannya secara jarak jauh [34]. Layanan ini memungkinkan seseorang menjalani kehidupan mereka secara normal sambil menerima perawatan kesehatan yang layak dan berkualitas tinggi dimanapun dan real-time. Tujuan dari sistem layanan ini adalah menyediakan data kesehatan secara real time untuk mendukung para profesional kesehatan. Melalui informasi ini, dokter dapat memperoleh penilaian kesehatan pasien tepat waktu dan dapat memberikan perhatian medis segera jika diperlukan. Kemampuan utama dari layanan ini terletak pada kemampuan untuk mengekstrak informasi dari data yang dikumpulkan. Layanan cerdas memungkinkan fasilitas kesehatan untuk mengumpulkan data yang dihasilkan oleh pasien setiap saat dan dimana saja. Data ini memberikan pedoman penting untuk pemberian layanan perawatan. Dengan demikian, layanan cerdas memiliki kapasitas untuk mengubah menjadi informasi adaptif yang dapat menciptakan layanan baru yang disesuaikan dengan kebutuhan pasien, mengikuti proses kustomisasi berkelanjutan. Proses tersebut diperlihatkan pada Fig.4

Smart tourism dapat dilihat sebagai perkembangan dari traditional tourism dan e-tourism dimana landasan untuk inovasi dan orientasi teknologi industri dan konsumen diletakkan lebih awal dengan adopsi informasi yang luas. Pada smart tourism, teknologi lebih dipandang sebagai suatu infrastruktur dibandingkan sistem informasi dan mencakup berbagai teknologi komputasi cerdas yang mengintegrasikan teknologi perangkat keras, perangkat lunak, dan jaringan untuk memberikan analitik yang membantu seseorang untuk membuat keputusan dari alternatif yang diberikan.[1] Pada e-tourism sumber data mayoritas bersumber dari informasi web, namun pada Smart tourism, data-data diperoleh dari berbagai sensor dan perangkat mobile.

\section{KESIMPULAN}

Layanan cerdas merupakan layanan baru yang dihasilkan dari kolaborasi antara penyedia layanan dan pengguna layanan. Perusahaan sebagai penyedia layanan bertransformasi tidak hanya menyediakan produk fisik, namun juga menyediakan layanan. Penelitian ini dilakukan untuk mengintegrasikan pengetahuan antara produk cerdas dengan sistem layanan cerdas. Konseptualisasi produk cerdas dilakukan dengan studi literatur terhadap penelitian terdahulu. Hal tersebut digunakan untuk mendapatkan karakteristik dari produk cerdas pada sistem layanan cerdas. Penelitian ini juga menyajikan berbagai topik dan fokus penelitian dalam konteks produk pada sistem layanan cerdas dengan menyertakan beberapa implementasi sistem layanan cerdas dan contoh produk cerdas dengan melakukan klasifikasi mengadopsi standar ISIC

\section{REFERENSI}


[1] U. Gretzel, M. Sigala, Z. Xiang, and C. Koo, "Smart tourism: foundations and developments," Electron. Mark., vol. 25, no. 3, pp. 179-188, Sep. 2015.

[2] S. K. Das, "Mobility management-A personal perspective," Comput. Commun., vol. 131, pp. 26-31, Oct. 2018.

[3] A. Valencia, R. Mugge, J. P. L. Schoormans, H. N. J. Schifferstein, and R. Schifferstein, "The Design of Smart Product-Service Systems (PSSs): An Exploration of Design Characteristics," Int. J. Des., vol. 9, no. 1, pp. 13-28, 2015.

[4] J. Anke, "Design-integrated financial assessment of smart services," Electronic Markets, Springer Berlin Heidelberg, pp. 1-17, 01-Jun-2018.

[5] T. Gavrilova and L. Kokoulina, "Smart Services Classification Framework," in Position Papers of the 2015 Federated Conference on Computer Science and Information Systems, 2015, vol. 6, pp. 203-207.

[6] R.-B. Wiegard and M. H. Breitner, "Smart services in healthcare: A risk-benefitanalysis of pay-as-you-live services from customer perspective in Germany," Electron. Mark., pp. 1-17, 2017.

[7] S. Dreyer, D. Olivotti, B. Lebek, and M. H. Breitner, "Focusing the customer through smart services: a literature review," Electron. Mark., 2019.

[8] K. Laubis, M. Konstantinov, V. Simko, A. Gröschel, and C. Weinhardt, "Enabling crowdsensing-based road condition monitoring service by intermediary," Electron. Mark., pp. 1-16, 2018.

[9] D. Beverungen, O. Müller, M. Matzner, J. Mendling, and J. vom Brocke, "Conceptualizing smart service systems," Electron. Mark., pp. 1-12, Nov. 2017.

[10] D. Beverungen, M. Matzner, and C. Janiesch, "Information systems for smart services," Inf. Syst. E-bus. Manag., vol. 15, no. 4, pp. 781-787, 2017.

[11] V. C. de Oliveira and J. R. Silva, "A service-oriented framework to the design of information system service,” J. Serv. Sci. Res., vol. 7, no. 2, pp. 55-96, Dec. 2015.

[12] M. Fan, J. Sun, B. Zhou, and M. Chen, "The Smart Health Initiative in China: The Case of Wuhan, Hubei Province," J. Med. Syst., vol. 40, no. 3, p. 62, Mar. 2016.

[13] J. M. Tien, "The next industrial revolution: Integrated services and goods," J. Syst. Sci. Syst. Eng., vol. 21, no. 3, pp. 257-296, Sep. 2012.

[14] J. Son, J. Park, K. Moon, and Y. Lee, "Resource-aware smart home management system by constructing resource relation graph," IEEE Trans. Consum. Electron., vol. 57, no. 3, pp. 1112-1119, Aug. 2011.

[15] N. V. Wünderlich, F. V. Wangenheim, and M. J. Bitner, "High Tech and High Touch," J. Serv. Res., vol. 16, no. 1, pp. 3-20, Feb. 2013.

[16] J. He, Y. Zhang, G. Huang, and J. Cao, "A smart web service based on the context of things," ACM Trans. Internet Technol., vol. 11, no. 3, pp. 1-23, Jan. 2012.

[17] A. Moawad, T. Hartmann, F. Fouquet, J. Klein, and Y. Le Traon, "Adaptive blurring of sensor data to balance privacy and utility for ubiquitous services," 2015.

[18] A. Yachir, K. Tari, Y. Amirat, A. Chibani, and N. Badache, "QoS based framework for ubiquitous robotic services composition," in 2009 IEEE/RSJ International Conference on Intelligent Robots and Systems, IROS 2009, 2009.

[19] L. Hong, Z. She, J. Ye, and X. Chen, "An exploration research of establishing e-service dimensions model by building up service quality indexes based on process interaction," 
in 2014 11th International Conference on Service Systems and Service Management (ICSSSM), 2014, pp. 1-5.

[20] H. Lee, H. Seol, H. Min, and Y. Geum, "The identification of new service opportunities: a case-based morphological analysis," Serv. Bus., vol. 11, no. 1, pp. 191-206, Mar. 2017.

[21] Y. Geum, H. Jeon, and H. Lee, "Developing new smart services using integrated morphological analysis: integration of the market-pull and technology-push approach," Serv. Bus., vol. 10, no. 3, pp. 531-555, Sep. 2016.

[22] S. Barile and F. Polese, "Smart Service Systems and Viable Service Systems: Applying Systems Theory to Service Science," Serv. Sci., vol. 2, no. 1-2, pp. 21-40, Jun. 2010.

[23] D. Budaev et al., "Conceptual design of smart farming solution for precise agriculture," Int. J. Des. Nat. EAcodynamics, vol. 13, no. 3, pp. 307-314, Aug. 2018.

[24] Jing Zhang and Bing Qi, "Studies on interactive service platform for smart grid," in 2011 IEEE PES Innovative Smart Grid Technologies, 2011, pp. 1-4.

[25] F. Folianto, Y. S. Low, and W. L. Yeow, "Smartbin: Smart waste management system," in 2015 IEEE Tenth International Conference on Intelligent Sensors, Sensor Networks and Information Processing (ISSNIP), 2015, pp. 1-2.

[26] A. Hammad, F. Vahdatikhaki, C. Zhang, M. Mawlana, and A. Doriani, "Towards the smart construction site: Improving productivity and safety of construction projects using multi-agent systems, real-time simulation and automated machine control," in Proceedings Title: Proceedings of the 2012 Winter Simulation Conference (WSC), 2012, pp. 1-12.

[27] K. Chopra, P. Moun, and Kapil, "Smart transport recommender system," in 2017 2nd International Conference on Telecommunication and Networks (TEL-NET), 2017, pp. $1-5$.

[28] B. Syed, A. Pal, K. Srinivasarengan, and P. Balamuralidhar, "A smart transport application of cyber-physical systems: Road surface monitoring with mobile devices," in Proceedings of the International Conference on Sensing Technology, ICST, 2012, pp. $8-12$.

[29] E. Zunic, S. Delalic, K. Hodzic, A. Besirevic, and H. Hindija, "Smart Warehouse Management System Concept with Implementation," in 2018 14th Symposium on Neural Networks and Applications (NEUREL), 2018, pp. 1-5.

[30] Wenyu Li, Lulu Jiang, and Zhenping Li, "Research on the task assignment problem of warehouse robots in the smart warehouse," in 12th International Symposium on Operations Research and its Applications in Engineering, Technology and M anagement (ISORA 2015), 2015, p. 5 .-5 .

[31] T. Lin, H. Rivano, and F. Le Mouel, "A Survey of Smart Parking Solutions," IEEE Trans. Intell. Transp. Syst., vol. 18, no. 12, pp. 3229-3253, Dec. 2017.

[32] V. Liyanage, A. Ekanayake, H. Premasiri, P. Munasing he, and S. Thelijjagoda, "Foody - Smart Restaurant Management and Ordering System," in 2018 IEEE Region 10 Humanitarian Technology Conference (R10-HTC), 2018, pp. 1-6.

[33] S. Du, F. Meng, and B. Gao, "Research on the application system of smart campus in the context of smart city," Proc. - 2016 8th Int. Conf. Inf. Technol. Med. Educ. ITME 2016, pp. 714-718, 2017. 
[34] M. Opazo-Basáez, S. G. Muhammad, D. Arias-Aranda, and V. Molina-Moreno, “A roadmap towards smart services in healthcare [Una hoja de ruta hacia los servicios inteligentes en la asistencia sanitaria],” Dyna, vol. 92, no. 1, pp. 22-27, 2017. 